\title{
The Use of Authentic Materials on Teaching Reading and Its Effects on Students' Reading Motivation
}

\author{
Vinda Ryandani, Joko Nurkamto, Teguh Sarosa \\ English Education Department \\ Teacher Training and Education Faculty \\ Sebelas Maret University of Surakarta
}

\section{Email:Vinda.Ryandani@yahoo.com}

\begin{abstract}
The goals of this research are to describe the use of authentic materials on teaching reading, the problems and the solutions in using authentic materials, and its effects on students reading motivation. This research was case study research. The sources of data were event, informant, and document. The techniques of data collection were observation, interview, and document. The results of the research are in determining the materials; the teacher considers criteria such as the topic and the difficult level of the text. The problems of the use of authentic materials are related to time constrain and the students' lack of vocabulary mastery, proper use of authentic materials gives positive effects on students reading motivation. The student have positive task orientation, ego involvement, need for achievement, high aspiration, goal-orientation, perseverance and tolerance of ambiguity.
\end{abstract}

Keywords: authentic materials, teaching reading, reading motivation

\section{INTRODUCTION}

Learning to read is considered important. It is stated by Budiantari, Nitiasih, and Budasi (2013) that learning to read is one of the most important things that should be accomplished by the students because it is their foundation for most of their future academic endeavors. It means that reading is the basic skill students should learn when someone would like to learn English and it can influence the other skill. It is also supported by Pang, Muaka, Bernhardt, and Kamil (2003) stating that learning to read is an important educational goal. They add that for both children and adults, the ability to read opens up a new world and opportunity. It means that reading is an important skill to be accomplished by both children and adults.
Commonly, reading becomes one skill that is emphasized more in education 
setting. In English lesson, reading is considered as one of important English skills that teacher expects the students to acquire. The statement is supported by Williams (1996) who states that students should be taught reading so that the students can have further practice of language they have already met through listening and speaking, the students can practice language in order to reuse it in writing, the students can learn how to make sense of texts, in transactional text formally or informally, in the form of recount, narrative, procedure, descriptive, news item, report, analytical exposition, hortatory exposition, spoof, explanation, discussion, review, public speaking in the academic context, and popular and authentic literature, in the real life." To help students to be able to reach the goal of reading - to be able to understand what the text trying to convey - one thing that is considered important is the teaching materials.

Teaching materials are the resources a teacher uses to deliver instruction to the students. It is supproted by Richard (2001) who states that teaching materials are a key component in most language program. It supports and facilitates the teaching and learning process. He adds that whether the teacher uses textbook, institutionally prepared materials or his or her own materials generally serves as the basis for much of the language input learners receive and the language practice that occurs in the classroom. Chanda et.al. (2000) add that teaching material enables everyone in a classroom situation to participate effectively. Since teaching material is important in the process of teaching and learning, the use of teaching material is one thing to be considered to be applied so that it can create an effective source of learning during the teaching and learning process.

Nowadays, authentic teaching materials begin to be used by some teachers in high school as an alternative teaching order to extract information they need from them, the students can find enjoyment through reading.

In teaching reading, there is a competency or a goal that the teacher expects the students to achieve at the end. That competency has been written in Permendiknas no 23 tahun 2006 stating that the students should be able to "understand the meaning of written interpersonal and

material in supporting and facilitating them in teaching reading for authentic material is considered as more motivating teaching material since it reflects the real life situation. It is supported by Pang, Muaka et.al (2003) who states that choosing reading materials that draw on students' lives, experiences, and interests is a good starting 
point. It means that teaching material is really important to be considered for the process of teaching and learning

It is believed that authentic material is considered as good and interesting teaching material to be used. It is also suggested by Silberstein (1994) to use text that are realistic in term of the students' reading needs and abilities, and that are authentic. He says that reading passages should be authentic in the sense that they resembles the "real-worlds" texts students will encounter and that they require the same approaches to reading. Students will learn best if they are involved in real-life situation. Authentic material brings students to real-life and meaningful context.

Tamo (2009) adds that bringing authentic materials into the classroom can be motivating for the students as it adds a real- life element to the student's learning experience. In a plain word, authentic materials are better since it is more interesting and represents the real-life situation.

Another research in the form of an action research about the use of authentic teaching materials has been conducted by AgungWicaksono in the second grade students of English Department Teacher Training and Education Faculty at one university in Kediri. The result showed that the result of this research was satisfying in the terms of: (1) the improvement of students' reading comprehension; (2) the improvement of teaching and learning process. It can be seen that there is an improvement on pre-test and post-test score. The score of pre-test and post-test has improved from the mean score of 63.01 into 71.78 for post-test 1 and 75.01 for post-test 2. Based on those score, it is quite clear that the use of authentic materials in teaching reading effects on students' improvement in reading. material can increase students' motivation to learn. Motivation to learn is an important aspect in the process of reaching the goal. It is said by Brown (2001) that it refers to the intensity of one's impetus to learn. So, the involvement of students during teaching and learning process and the effectiveness of the process are influenced by students' motivation they bring in the classroom.

An experiment about the use of authentic teaching materials in one state junior high school in Kediri which has been conducted by Fadeli showed that authentic materials are more effective than textbook to teach reading for that school. There was an improvement of students' score after using authentic material as the source of material for reading. He adds that since authentic materials are taken from the world around students' daily life, they are able to attract students to be more active in the teaching and learning process. It means that authentic

Those two previous research showed that the use of authentic materials in teaching reading gives positive effect on students' reading achievement and motivation. Based on those two results, the researcher conducted a research to get the problem faced in using authentic materials, and the solution offered by the teacher, and to what extend it motivates students in reading. The writer hopes that the result of this research is able to improve the knowledge of teacher in teaching learning process.

\section{RESEARCH METHODS}

The research belongs to case study. This research was conducted at one senior high school in Karanganyar. The participant of the research was one class of the third grade students. The participant of the 
research was class XII IPA 1 consisting 20 female students and 10 male students. That class was purposively chosen to be the participant of the research because the teacher has recommended the class to the researcher for the condition of the class was conducive and the students were active enough. By those conditions, the researcher thought it would help the researcher to obtain further information needed. As Ritchie and Lewis (2003) state, the unit of participant is chosen because they have particular features or characteristics which will enable to give detailed exploration and understanding of the central themes and puzzles which the researcher wishes to study.

In this research, the sources of data were event, informant, and document. The techniques of data collection used were observation, interview, and document collection. The researcher observed the provides up to date and real information so that the students can broaden their knowledge by reading those articles.

In determining the authentic materials to be used in the classroom, the teacher considers some aspects so that they can be effective materials to be used. The first is the topic. The topic chosen should be interesting for the students so that it makes the students attracted with the text. This is usually related to the students' world or happening issues. When the students are attracted with the text, they will be more active during reading activities. The second is the difficulty level of the text. It is related to readability. Before using the authentic materials to be used, teacher always tries to find a text which is appropriate with the students' level of understanding.

In teaching reading using authentic materials, the first activity that the teacher does is building the students' background knowledge about the text. It is done to help the students to relate the real life situation teaching and learning process during reading class. The researcher interviewed the teacher to find the deep understanding about how teacher uses authentic material in the classroom and interviewed the students to know the effects of using authentic materials on students' reading motivation. The researcher also collected three lesson plans which were used by the teacher for teaching reading which were analyzed to find out what kinds of authentic material which were usually used by teacher and how they were used in the classroom when teaching reading

\section{RESEARCH RESULT TND DISCUSSION}

The results shows that the materials commonly used for teaching reading are usually in the form of articles. They are usually taken from the internet because they are usually easy to get. Besides, they also

and the text. When the students are able to relate their knowledge and the text, they will be able to understand the text more easily. After that, the teacher gives the students a task related to the text. The teacher usually asks the students to discuss the task in a group. By doing so, the students are able to share their ideas about the text and the task. Finally, the teacher asks the students to do debates or present their understanding of reading the text. The teacher integrates it with speaking because she thinks that the students will be bored when the activity is just reading and answering question. By doing so, the students learn the language in a meaningful way.

As some experts say that authentic materials do not provide specifically for pedagogical purposes, so there are some problems when using it. The first problem 
the teacher finds is dealing with the vocabulary. Sometimes, teacher finds that the students have less vocabulary mastery. So, they sometimes find difficulties in understanding the text.The second is dealing with time constrain. The students sometimes spend a lot of time to understand the text using authentic material.

To overcome the problem arising when using authentic materials, teacher usually tries to build the students' background knowledge about the text. Besides, teacher always devides the students into some groups and asks them to work in a form of discussion because the teacher thinks that this activity is effective enough to make the students active in sharing their ideas and it will be easier for the students to understand the text. Teacher also acts as a good helper for the students. When the students find difficulties in understanding the text, they can asks to the teacher

authentic materials is established with interest and without difficulty they can participate actively in learning and in the same way their motivation levels may raise.

Knowing that students' interest belong to factors that are able to motivate students, it should be one criterion that a teacher should consider when choosing authentic materials. It is related to suitability of the text with the students. The choices of the topic should be matched with the students' interest or students' world. It is the same as Daskalos\& Ling (2005) state that if the theme is familiar to the student, it will also be easier to discuss in class. At the same time it enables the student to activate his or her cultural background and the knowledge that he or she already possesses.

Articles from the internet can be one of materials which can be used in the classroom. They can be used since it is easy to be searched, it has various form and is not easily out dated. It is also stated by Ryan
By using authentic materials, the students show that their motivation rises. They have positive task orientation. They are able to work with the text and the task well. Students also show that they have ego involvement. All of the groups are active in discussion. Students also have needs for achievement andgoal-orientation. Students set the goal that they should understand the text. The students show that they have perseverance or high effort of learning. Students also show that they have tolerance of ambiguity about the text. They also have high aspiration about the text so that they try to be successful in understanding the text.

If the teacher chooses authentic materials which can interest the students and use it properly in the classroom, the students will be motivated. It is in line with as Oguz and Bahar (as cited in Baghban, 2011) who contend that if learners' interaction with

(2003) that the internet is perhaps the most logical, if certainly not the only, source of materials especially for teachers in an EFL context. He adds that good reasons to look to the Internet for authentic materials are that the internet is interactive, continuously updated, provides visual stimulation and most of us in developing or advanced countries have unlimited access to it.

As we know that authentic materials do not produce for pedagogical purpose, the materials usually contain lots of difficult words and complex structure. So, the teacher should also consider the readability of the text. The choices of materials should be matched with the learners' language level in which the vocabulary is not so difficult and the structure of the text is not so complicated for students, so the students can comprehend it. It is in line with Yu-Feng (as cited in Baghban, 2011) who also mentions the 
importance of level of the learners as a determining factor in choosing appropriate authentic materials. It makes the students interest with the text and they feel that it is easy to be understood. It is also same as Daskalos\& Ling (2005) who is inspired by Krashen stating that text should always be just above a student's level of proficiency. By this way the student is challenged but will not find the text impossible to understand and at the same time the student will achieve satisfaction when the text is understood. He adds that the language of a text should be accessible while at the same time challenging and stimulating for the reader - adding new words to the reader's vocabulary.

In teaching reading using authentic materials, teacher has an important role. Teacher should apply the appropriate teaching activities and method when using authentic materials so that the students can important to build students' background knowledge toward the text they are reading.

In teaching reading using authentic materials, it is not only the text that should be authentic but the task should also be authentic. In designing the task, teacher also applies discussion, presentation or debates based on the communicative purposes of the text that the students learn. The teacher integrates it with speaking. Discussion, presentation or debates is also good ways to apply when using authentic materials. By that way, the students can learn authentic materials in a meaningful way. It is same as Mishan (2005) saying that in order for tasks to be authentic, they should be designed to reflect the original communicative purpose of the text on which they are based, be appropriate to the text on which they are based, elicit response to/engagement with the text on which they are based, approximate real-life tasks, activate learners' existing knowledge of the target language and culture, and involve purposeful communication between learners. understand the text. As Daskalos\& Ling (2005) says that this should of course be done with the teacher acting as a guiding force. The teacher should present various ways of working with a text to the students, listen to their suggestions and perhaps create a combined list of activities. Furthermore, the method should be adapted to fit the needs of the different classes. What is perfect for one class will not necessarily work in another.

Building students' background knowledge is considered important to do because it helps the students relate their knowledge about the topic with the text they are reading so that it makes them feel easier to understand the text. It is also supported by Yuk\& Lee (1995) who states when learners read an authentic text, their prior knowledge, interest, and curiosity makes it easier for them to engage with it. So, it is really

Finally, when the students have motivation, they will perform better. The students also give positive responses to the text and the task. They are active in reading the text and doing the task. When there are difficulties, they do not feel discouraged with the text instead they have higher motivation in order to be able to understand the text. It is stated by Naiman et al. (as cited in Penny Ur, 2000) that the characteristics of motivated learner are they have positive task orientation, ego involvement, need for achievement, high aspiration, goalorientation, perseverance and tolerance of ambiguity. When students have high motivation, they will have higher intention to learn. As Brown (2001) states thatif they are motivated, they will learn; and if not, they will not. Finally, the students 
are successful in understanding the text and they have good achievement in doing the task.

\section{CONCLUSION AND SUGGESTION}

From the result of the research, the conclusions that can be drawn is the proper use of authentic materials include the choices of the materials for teaching reading, such as considerations which are the topic and the difficult level of the text. There are also some problems when using authentic materials that are it spends more time for the students to understand the text and the students' vocabulary mastery but it can be overcome by building the students' background knowledge or prior knowledge about the text, forming the students in a group discussion or to works in group, helping and guiding the students, making an evaluation.

Brown, D. (2001). Teaching by Principles: An Interactive Approach to Language Pedagogy Second Edition. New Vistas: Longman.

Brown, D. (2004). Language Assessment: Principles and Classroom Practices. San Fransisco: Longman.

Budiantari, P.Y, et.al. (2013). Developing Anthentic Reading Material for The Tenth Year Students of State Vocational High School 1 Kubutambahan. E-Journal Program PascasarjanaUniversiasPendidikanG a nesha Program StudiPendidikanBahasaInggris, 1(1).

Daskalos, K \& Ling, J. J.(2005). The use of authentic and adapted texts in the study of English in Two Swedish Upper Secondary Schools and A Study of Student and Teacher Attitudes towards These Texts. Höstterminen: Lärarutbildningen 60 Poäng.
It will be better for the teacher to keep on using authentic materials for teaching since authentic materials give positive effects on students' reading motivation in terms positive task orientation, ego involvement, high aspiration, needs for achievement, goal-oriented, high perseverance and tolerance of ambiguity.

\section{BIBLIOGRAPHY}

Aebersold, J \& Field, M. L. (1997). From Reading to Reading Teacher: Issues and Strategies for Second Language Classroom. Cambridge: Cambridge University Press.

Al-Azri, R. H \& Al Rashdi, M. H. (2014). The Effect of Using Authentic Materials in Teaching. International Journal of Scientific \& Technology Research, 3(10).

Fadeli. (2009). The Effectiveness of Authentic Material in Teaching Reading viewed from Students' English Learning English. English Education department Graduate school sebelasMaretUniversity.Unpublished.

Mishan, F. (2005). Designing Authenticity into Language. UK: Bristol.

Pang, Elizabeth S et.al. (2003). Teaching Reading. Switzerland: IBE Publication unit.

Permendiknas no 23 tahun 2006tentang SKL

Richard, J C. (2001).Curriculum Development in Language Teaching. Cambridge: Cambridge University Press.

Ritchie, J \& Lewis, L. (2003). Qualitative Research Practice: A Guide for Social 
Science Students and Researchers. London: Sage Publication.

Ryan, J. (2013). Authentic Materials in an EFL Curriculum: Appropriateness, Selection, Activity Design and promoting a Global Perspective, 14(1).

Silberstein, S. (1994). Technique and Resources in Teaching Reading. New York: Oxford University Press.

Tamo, D. (2009). The Use of Authentic Materials in Classroom.LCPJ, 2 (1).

Ur, P. (199). A Course in Language Teaching: Practice and Theory. Cambridge: Cambridge University Press.
Wicaksono, A. (2008). Using Authentic Materials to Improve The Students' Reading Comprehension (A Classroom Action Research in the Second Grade Students of English Department Teacher Training and Education Faculty Nusantara PGRI Kediri University in Academic Year 2008/2009). Thesis. Sebelas Maret University. Unpublished.

Williams, E. (1996). Reading in the Language classroom. Hertfordshire: Macmillan Publishers Ltd.

Yuk, W \& Lee, C. (1995). Authenticity revisited: Text Authenticity and Learner Authenticity: ELT Journal, 49 (4). 